DOI: https://doi.org/10.24867/13GI23Puzigaca

\title{
ISTRAŽIVANJE ASPEKATA PROMENA PROIZVODNIH SISTEMA PRELASKOM NA INDUSTRIJU 4.0
}

\section{RESEARCH OF ASPECTS OF CHANGES IN PRODUCTION SYSTEMS DUE TO TRANSITION TO INDUSTRY 4.0}

\author{
Jelena Puzigaća, Fakultet tehničkih nauka, Novi Sad
}

\begin{abstract}
Oblast - INDUSTRIJSKO INŽENJERSTVO
Kratak sadržaj - Predmet rada jeste sagledavanje $i$ opis promena i napretka kroz istoriju industrijskih revolucija, sa fokusom na opis tehnologija koje se trenutno koriste u industriji 3.0 i predstavljanje tehnologija koje počinju da se pojavljuju $i$ razvijaju se u okviru industrije 4.0, uz kreiranje idejnog rešenja faza implementacije pomoću dijagrama toka.
\end{abstract}

Ključne reči: Industrija 4.0, industrijska revolucija

\begin{abstract}
The subject of the paper is to review and describe changes and progress through the history of industrial revolutions, with a focus on describing technologies currently used in Industry 3.0 and presenting technologies that are beginning to emerge and develop within Industry 4.0, including creation of a conceptual solution of the implementation phases using flow diagram.
\end{abstract}

Keywords: Industry 4.0, industrial revolution

\section{UVOD}

Prva industrijska revolucija započela je oko 1750. godine u Engleskoj i trajala je narednih sto godina. Najvažniji izumi koji su proistekli iz ovog perioda su parna mašina i nove mašine za proizvodnju tekstila. Nakon toga je započeo period druge industrijske revolucije koji je bio dominantan prvenstveno u Americi, i trajao je do 1940. godine. U ovom periodu došlo je do pronalaska novih izvora energije $u$ vidu motora sa unutrašnjim sagorevanjem, a kasnije i struje. Pronalazak novih izvora energije u toku ova dva perioda, omogućio je niz novih promena u oblasti proizvodnje, transporta i komunikacije. Proizvodnja je napredovala od potpuno manuelnog rada ka mašinskoj proizvodnji, i kasnije se razvila $u$ proizvodnju u fabrikama. Glavni izum ovog perioda vezan za proizvodnju bila je pokretna traka. Izgrađene su pruge, a ubrzo nakon toga pojavili su se i parobrodi. Automobili su ubrzo postali novi vid prevoznog sredstva, a omogućen je i vazdušni transport. Omogućena je komunikacija pomoću telegrafa $\mathrm{i}$ telefona. Pojava kompjutera i interneta označila je početak treće industrijske revolucije u drugoj polovini 20. veka. Za razliku od ranije osmišljenih mašina koje su obezbedile pomoć i odmenile čoveka $u$ fizičkom radu,

\section{NAPOMENA:}

Ovaj rad proistekao je iz master rada čiji mentor je bio dr Milovan Lazarević, red. prof. kompjuteri su imali mogućnost da donekle zamene čoveka u umnom radu zbog mogućnosti računanja i obrade velike količine podataka u kratkom vremenu. Karakteristično za period treće industrijske revolucije jeste široka primena elektronike, upravljanje mašinama pomoću kompjutera i automatizacija procesa rada [1]. Promene koje se očekuju u narednom periodu industrijske revolucije, a koje će znatno promeniti način proizvodnje su:

- Sajber-fizički sistemi (Cyber Physical Systems CPS), koji se zasnivaju na dubokoj povezanosti mašine i softvera koji se koristi za kontrolu rada, podešavanje i upravljanje mašinom, i omogućavaju njihov autonoman rad uz minimalno učešće čoveka

- Internet stvari (Internet of Things - IoT), kao novi način povezivanja fizičkih uređaja koji u svom radu koriste razne softvere, senzore i tehnologije, i omogućava njihovo povezivanje i brzu razmenu podataka i informacija pomoću interneta

- Razvoj internet mreže i informacionokomunikacionih tehnologija (ICT),

- Veštačka inteligencija (Artificial Inteligence - AI),

- Tehnologije virtuelne (Virtual Reality - VR) i proširene realnosti (Augmentet Reality - AR), i

3D štampa (3D printing).

Pored razvoja novih tehnologija, očekuju se i znatne promene u načinu rada i organizaciji rada.

\section{TEHNOLOGIJE INDUSTRIJE 4.0}

\subsection{Promene proizvodnih tehnologija}

U periodu treće industrijske revolucije razvile su se razne tehnologije i metodologije koje su značajno uticale na proizvodnju. Obeležja ovog perioda su razvoj automatizacije, primena robota u proizvodnji, korišćenje SCADA sistema za upravljanje i nadzor, računarom podržan dizajn i proizvodnja (CAD/CAM), RFID sistemi, reverzibilno inženjerstvo, i primena Lean metodologije za unapređenje procesa uz smanjenje gubitaka.

$\mathrm{U}$ periodu četvrte industrijske revolucije takođe su se razvile različite nove tehnologije koje će znatno uticati na sve aspekte proizvodnog sistema. U nastavku će biti više reči o njima.

\subsection{Big data}

Big data, ili u prevodu ,Veliki podaci“, predstavljaju generisanu ogromnu količinu podataka koja postoji, i koja se konstantno proširuje. Od trenutka pojave interneta, 
dostupnost i količina podataka koja nastaje i koja se deli je naglo počela da raste, i od tada se novi podaci stalno dodaju. Ovi podaci se definišu pomoću šest karakteristika, koje se još nazivaju i 6V, po uzoru na engleske nazive: 1) Količina (Volume), 2) Brzina (Velocity), 3) Raznovrsnost (Variety), 4) Tačnost (Veracity), 5) Vrednost (Value) i 6) Varijabilnost (Variability). Svi podaci koji se se prikupljaju i skladište, mogu se podeliti u tri oblika: strukturirani, nestrukturirani i delimično strukturirani podaci. Ovako ogromnu količinu podataka nije moguće obraditi pomoću običnih računara, već je potrebno koristiti internet servere koji imaju veći potencijal obrade, i mnogo veću memoriju.

Ovakvi serveri zovu se „Oblak“ ili „Cloud“, a obrada podataka u njemu naziva se „Cloud computing“. Koraci koji bi trebalo da se prate prilikom postavljanja i početka korišćenja sistema velikih podataka su: 1) Postavljanje strategije za korišćenje velikih podataka, 2) Identifikovati izvore velikih podataka, 3) Prikupljanje i upravljanje podacima, 4) Analiza prikupljenih podataka i 5) Donošenje odluka na osnovu prikupljenih podataka [2].

\subsection{Internet stvari (Internet of Things - IoT)}

Internet stvari (Internet of Things - IoT) podrazumeva povezanost velikog broja različitih uređaja pomoću interneta, čime je omogućeno deljenje podataka između njih, bez obzira na to na kojoj udaljenosti se oni nalaze. $\mathrm{Na}$ ovaj način razni uređaji mogu da primaju i dele podatke mnogo većom brzinom, i to bez učešća čoveka u procesu. Za ovakve uređaje, koji poseduju neophodne senzore pomoću kojih vrše prikupljanje informacija, i u koje je ugrađena određena vrsta inteligencije po kojoj rade, kaže se da su "pametni uređaji“.

Pametni uređaji mogu da nauče i predvide akciju koju je potrebno uraditi, na osnovu zadatih inputa od strane čoveka, ili prikupljenih podataka preko drugih uređaja. Ovaj vid komunikacije se naziva i machine-to-machine (M2M), zbog samostalnog prenosa podataka između mašina. Povezanost uređaja preko interneta može doneti različite benefite $\mathrm{u}$ industrijskim procesima, kao što su veća fleksibilnost, efikasnost, brže prikupljanje informacija i donošenje odluka [2].

\subsection{Cyber-physical Production Systems (CPPS)}

Sajber-fizički sistemi (Cyber-physical Systems - CPS) zasnivaju se na međusobnoj povezanosti fizičkih sistema pomoću interneta, pri čemu oni za svoj rad koriste podatke koji su u sklopu velikih podataka dostupni na intenetu.

Preduslov za nastanak sajber - fizičkih sistema bio je razvoj računara, razvoj informaciono - komunikacionih tehnologija, razvoj veštačke inteligencije, pojava pojma velikih podataka i interneta stvari. Sajber-fizički proizvodni sistemi (Cyber-physical Production Systems CPPS) predstavljaju sajber-fizičke sisteme koji se koriste $\mathrm{u}$ proizvodnji. Ovaj način povezanosti i komunikacije omogućava značajan nivo autonomije tehnoloških sistema u njihovom radu, jer koristeći dostupne internet podatke, $\mathrm{i}$ uz primenu odgovarajuće veštačke inteligencije, mašine same mogu da vrše analizu i donose odluke. Sajber-fizički proizvodni sistemi mogu se opisati kao sistemi koji koriste senzore za prikupljanje podataka koji nastaju $\mathrm{u}$ proizvodnim procesima, analiziraju podatke i komuniciraju sa drugim uređajima koristeći veštačku inteligenciju i internet, i samostalno vrše podešavanja i upravljanje izvršnim elementima. Sajber-fizički proizvodni sistemi obezbeđuju decentralizovanu kontrolu proizvodnih procesa, koja ujedno predstavlja i jednu od važnih karakteristika industrije 4.0 [2].

\subsection{Digitalni modeli proizvodnih sistema (Digital twins)}

Uz korišćenje sajber-fizičkih proizvodnih sistema, potrebno je kreirati digitalne modele koji će predstavljati realne fizičke sisteme prisutne u proizvodnji. Ovakvi modeli nazivaju se digitalni blizanci jer treba u digitalnoj formi da predstave i opišu delovanje fizičkih sistema, uz težnju ka tome da oni budu što sličniji ili isti. Prilikom modelovanja, treba voditi računa o tome da se predstave svi fizički sistemi koji su međusobno povezani i da se na određeni način opišu sve interakcije koje između njih postoje. Još jedan od uslova je da se obezbedi preslikavanje svih promena stanja iz realnosti u digitalni model, što se postiže povezivanjem i prenošenjem podataka preko odgovarajućih senzora.

$\mathrm{Na}$ ovaj način je olakšano praćenje svih dešavanja $u$ realnom sistemu preko virtuelnog modela, i uočiti promene u realnom vremenu. Pomoću digitalnih modela moguće je planirati proizvodne procese pre nego što se započne proizvodnja u realnosti [3].

\subsection{Peta generacija mobilne komunikacije - 5G}

Od 1980-ih godina, mobilne komunikacije su doživele promene od $1 \mathrm{G}$ do $4 \mathrm{G}$ uz napredak svake decenije, a trenutno je u toku prelazak na petu generaciju mobilne komunikacije, koja treba da obezbedi bolje povezivanje uz minimalno kašnjenje prilikom prenosa. $5 \mathrm{G}$ je standard sledeće generacije interneta, koji u industriji 4.0 treba da omogući tehničku podršku u aplikacijama zasnovanim na veštačkoj inteligenciji.

Ovakav internet treba da obezbedi ultra pouzdanu komunikaciju sa malim kašnjenjem (Ultra-Reliable LowLatency Communication - URLLC), poboljšani mobilni širokopojasni pristup (enhanced Mobile Broadband eMBB) i masivnu mašinsku komunikaciju (massive Machine-Type Communications - mMTC) [5].

\subsection{Veštačka inteligencija}

veštačka inteligencija u okviru Industrije 4.0 treba da obezbedi ostvarenje takozvane "pametne proizvodnje" u kojoj mašine poseduju određenu vrstu veštačke inteligencije, pomoću koje mogu da obrađuju veliku količinu podataka i na osnovu prethodno definisanih pravila donose odluke, i preduzimaju određene akcije. Ovim se postiže veći stepen automatizacije, smanjuje se potreba prisustva čoveka, i ubrzavaju se procesi.

Tehnološki sistemi u proizvodnji koji rade na principu veštačke inteligencije treba da imaju sposobnost nadgledanja, analiziranja, i provere podataka i parametara koji se mere, kako bi na osnovu toga mogli da donose odluke o tome koje akcije je potrebno izvršiti.

Primena veštačke inteligencije je neizbežna u tehnologiji industrije 4.0 koja obuhvata brz prenos i obradu ogromne količine podataka, povezanost i komunikaciju između mašina i proizvoda, i reakciju u realnom vremenu [4]. 


\subsection{Virtuelna i proširena realnost}

Virtuelna realnost (Virtual reality - VR) predstavlja simulaciju stvarnog ili imaginarnog okruženja pomoću računara, a proširena realnost (Augmented reality - AR) omogućava dodavanje određenih simuliranih delova $u$ realno okruženje. Oblasti primene sistema virualne i proširene realnosti u proizvodnji mogu biti veoma široke, i uključuju primenu u razvoju i dizajnu proizvoda, programiranju robota, planiranju fizičkog rasporeda mašina, preventivnom održavanju, korišćenju CNC mašina, obukama za procese montaže i u logističkim procesima [2].

\subsection{Primena 3D štampača - 3D printing}

3D štampa predstavlja jedan vid proizvodnje prilikom kojeg se proizvod štampa na osnovu postojećeg 3D digitalnog modela. Ovaj način proizvodnje se naziva još i aditivna proizvodnja (Additive Manufacturing), jer se za razliku od većine drugih procesa obrade i proizvodnje, proizvod kreira dodavanjem materijala $\mathrm{u}$ slojevima. Materijali koji se najčešće koriste su različiti oblici plastike ili metala. Pomoću 3D štampača moguće je proizvesti proizvod različitih kompleksnih oblika, za relativno kratko vreme. U poređenju sa procesima livenja koji se takođe koriste za dobijanje kompleksnijih delova, proces 3D štampanja je jeftiniji, ne zahteva izradu kalupa i naknadnu obradu površina radi postizanja odgovarajućeg kvaliteta. Zbog ovakvih karakteristika, 3D štampa je pogotovo pogodna za izradu prototipa ili jedinstvenih delova po želji kupca [2].

\subsection{Bežična automatizacija}

Primena bežičnih tehnologija za povezivanje $u$ industrijskim automatizovanim sistemima donosi određene prednosti kao što su brži prenos podataka, veća pouzdanost, fleksibilnost, produktivnost i eliminacija potrebe za korišćenjem kablova. Mreža bežično povezanih senzora (Wireless Sensor Network - WSN) predstavlja mrežu senzora koji se u proizvodnji koriste za nadgledanje i prikupljanje podataka, i imaju sposobnost da komuniciraju i razmenjuju informacije uz bežičnu povezanost. Kada je u pitanju opseg mreže, mogu postojati bežične LAN (Local Area Network) mreže ili bežične WAN (Wide Area Network) mreže koje imaju velike širine opsega. Ovakve mreže koje se koriste u industrijskim postrojenjima dobile su naziv industrijske mreže bežično povezanih senzora (Industrial Wireless Sensor Network - IWSN). Kako bi ovakva komunikacija bila moguća, bežični uređaji koji čine ove mreže moraju biti opremljeni senzorima, baterijom, radiom, memorijom i moraju imati mogućnost obrade podataka [6].

\subsection{Sigurnost podataka u industriji 4.0 - Syber security}

$\mathrm{U}$ industriji 4.0 koja podrazumeva povezanost i razmenu ogromne količine podataka preko interneta, sigurnost podataka je veoma bitna stavka. Uz korišćenje ovakvih tehnologija znatno se povećava rizik od napada hakera $i$ pojavljivanja industrijske špijunaže. Ovo znači da će prilikom implementacije naprednih internet tehnologija $u$ sklopu industrije 4.0, biti potrebno osigurati da su mreže koje se koriste izolovane i zaštićene, uz korišćenje odgovarajuće enkripcije.

\section{FAZE IMPLEMENTACIJE INDUSTRIJE 4.0}

Aktivnosti koje je potrebno uraditi kako bi se izvršio prelaz sa industrije 3.0 na industriju 4.0 mogu se podeliti u četiri faze implementacije.

U prvoj fazi je neophodno obezbediti digitalno opisivanje, prikazivanje i praćenje svih procesa koji se u proizvodnom preduzeću odvijaju, druga faza treba da obuhvati horizontalnu integraciju automatizovanih mašina koje se koriste u proizvodnji, u trećoj fazi se omogućava vertikalna integracija i povezivanje procesa unapređenim metodama razmene podataka, i konačno, cilj četvrte finalne faze jeste postizanje automatske kontrole i nadzora proizvodnih procesa [2].

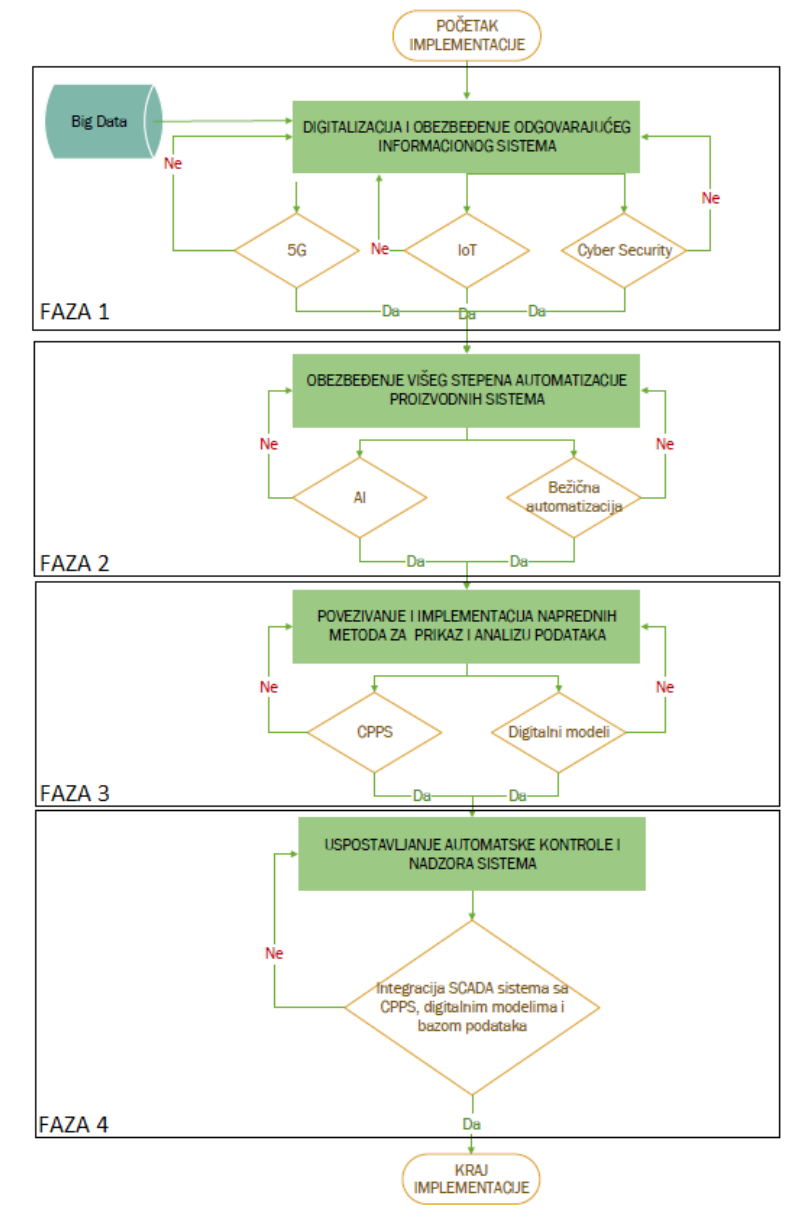

Slika 1. Dijagram toka faza implementacije Industrije 4.0

\section{PRIMERI PRIMENE TEHNOLOGIJA INDUSTRIJE 4.0}

\subsection{Sistem za automatsku identifikaciju}

Automatic Identification System (AIS) predstavlja sistem za unapređeno automatsko praćenje (traceability) komponenti i proizvoda, na osnovu njihovih karakterističnih oznaka. Prednost korišćenja ovakvog sistema je kreiranje baze podataka koja sadrži informacije o trenutku u kojem je određeni proizvod proizveden, i o tome koje komponente se u njemu nalaze. Kada je reč o pojedinačnim komponentama, najčešće se prate one komponente koje imaju veliki uticaj na kvalitet i osnovnu funkcionalnost proizvoda. Za ove komponente moguće je pratiti i zapisivati rezultate određenih testova, ukoliko one prolaze kroz test u toku proizvodnje. Prednost ovakvog načina 
praćenja je mogućnost provere i analize uočenog nedostatka ukoliko dođe do reklamacije od strane kupca.

\subsection{D štampanje}

U kompaniji Grundfos, tehnologija 3D štampe se koristi za izradu raznih plastičnih delova manjih dimenzija. U ove delove najčešće spadaju različiti jednostavni alati koji se koriste u sklopu procesa montaže na liniji, razni delovi prilagođeni specifičnim potrebama na određenim delovima opreme, ili delovi koje je moguće nabaviti eksterno, ali je isplativije i brže napraviti model i po potrebi ga odštampati na štampaču. Takođe, 3D štampač se koristi i za izradu prototipova pojedinih alata, kako bi se proverila njegova funkcionalnost i uočili mogući nedostaci pre nego što se pređe na izradu.

\subsection{Praćenje proizvodnje u realnom vremenu}

Pomoću aplikacije kao što je Blackbird, koja služi za prikupljanje podataka koji se generišu u proizvodnji u realnom vremenu, moguće je značajno unaprediti kvalitet i analizu podataka, a samim tim je obezbeđeno donošenje ispravnijih odluka i akcija. Moguće je pratiti podatke kao što su broj proizvedenih komada, trajanje i uzroci zastoja, količinu i uzroke škarta/dorade i efikasnost opreme.

\subsection{VR Cell i virtuelna poseta}

VR (Virtual Reality) Cell predstavlja prostoriju koja je izgrađena za potrebe korišćenja VR tehnologije za obuku operatera za procese montaže u kojima će kasnije učestvovati na proizvodnim linijama, i za učenje pravila ponašanja prilikom boravka u fabrici. Takođe, koristi se i robot pomoću kojeg je moguća virtuelna poseta fabrici iz bilo koleg dela sveta.

\subsection{Vision sistem}

Vision sistem predstavlja jedan oblik veštačke inteligencije koji je opremljen kamerom i u pomenutom proizvodnom sistemu se koristi za proveru kvaliteta proizvoda. Ovi sistemi se najčešće postavljaju na kraju proizvodne linije, na mestu gde je montiran ceo proizvod. Sistem funkcioniše tako što kamera snima kritične tačke proizvoda za koje je prethodno definisano da ih je potrebno proveriti, i one se upoređuju sa slikama željenog stanja. Program veštačke inteligencije vrši upoređivanje i prijavljuje se greška ukoliko se uoči odstupanje.

\subsection{Preventivno održavanje}

Procesi preventivnog održavanja se pažljivo planiraju i sve akcije koje je potrebno uraditi na određenoj mašini se beleže u vidu liste zadataka (Equipment Task List) u SAP sistemu. Svaka lista zadataka se sastoji iz određenog broja PM (Preventive Maintenance) ordera koji su vezani za broj opreme na kojoj se izvode. Prilikom kreiranja liste, potrebno je odrediti sve akcije koje je neophodno preduzeti kako bi se smanjila verovatnoća zastoja ili otkaza bilo kojeg dela mašine.

Ove aktivnosti najčešće podrazumevaju inspekciju određenih delova mašine i evaluaciju stanja, preventivnu zamenu delova, podmazivanje delova ili čišćenje. Za svaku aktivnost se određuje potrebna frekvencija njihovog izvođenja u skladu sa preporukama proizvođača opreme i delova, ili na osnovu procene inženjera. Frekvencija se određuje postavljanjem vremenskog intervala ili podešavanjem vrednosti brojača koji prati broj proizvedenih proizvoda.

\section{PREDLOZI ZA UNAPREĐENJA}

$\mathrm{U}$ radu su predstavljena tri predloga za unapređenje tehnologija industrije 4.0 koje se koriste u kompaniji Grundfos. Prvi predlog je unapređenje sistema za automatsku identifikaciju preko kojeg bi se dodatno pratila još jedna komponenta proizvoda, i svaka od njih imala bi svoj jedinstveni serijski broj. Drugi predlog vezan je za unapređenje preventivnog održavanja na liniji gde bi se kreirali PM orderi i za eksterno održavanje šrafilica radi jednostavnijeg i bržeg praćenja i planiranja. Treći predlog je digitalizacija QRQC (Quick Response Quality Control) table koja se u papirnom obliku popunjava na liniji.

\section{ZAKLJUČAK}

Tehnologije četvrte industrijske revolucije treba da obezbede bržu proizvodnju uz održavanje konkurentnosti na tržištu. Ove tehnologije treba da obezbede digitalizaciju, široku povezanost uređaja preko interneta, dostupnost podataka i brzinu njihove razmene. Navedene prednosti su veoma važne u proizvodnom okruženju gde je potrebno imati prave podatke u realnom vremenu, kako bi se na osnovu njih donela ispravna odluka i preduzela neophodna akcija.

Povezanost mašina preko interneta i prikupljanje podataka pomoću bežičnih senzora obezbediće funkcionisanje sajber-fizičkih sistema, koji će uz to imati ugrađenu veštačku inteligenciju koja omogućava dodatnu autonomiju. Nove tehnologije kao što su 3D štampanje, virtuelna i proširena realnost, unaprediće proizvodnju i kvalitet mnogobrojnih procesa iz proizvodnog okruženja. Cilj je da se obezbedi što veći nivo automatizacije i sposobnost mašina da samostalno funkcionišu, vrše analizu promena stanja i donose odluke o potrebnom podešavanju u skladu sa uočenim izmenama. Jedna od bitnih stavki jeste postizanje visoke fleksibilnosti uz mogućnost brzog odgovora na potrebe kupaca.

\section{LITERATURA}

[1] James L. Outman - Industrial Revolution. Almanac. Vol. 1-UXL (2003)

[2] Kaushik Kumar, Divya Zindani, J. Paulo Davim Industry 4.0: Developments towards the Fourth Industrial Revolution, Springer Singapore (2019)

[3] The digital twin of the production 1 Automotive Manufacturing | Siemens Global (21.12.2020.)

[4] Mark Skilton,Felix Hovsepian, The 4th Industrial Revolution Responding to the Impact of Artificial Intelligence on Business, Palgrave Macmillan (2018)

[5] Xiwen Wang, Longxiang Gao - When 5G Meets Industry 4.0, Springer (2020)

[6] Abbasi, Qammer H.Hussain, Sajjad Imran, Muhammad A - Wireless Automation As an Enabler for the Next Industrial Revolution, Wiley (2020)

\section{Kratka biografija:}

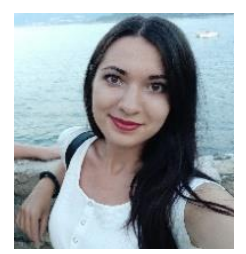

Jelena Puzigaća rođena je u Novom Sadu 1995. god. Master rad na Fakultetu tehničkih nauka iz oblasti Industrijskog inženjerstva - Projektovanje proizvodnih i uslužnih procesa odbranila je 2021.god. Kontakt: jelena.puzigaca@gmail.com 